\title{
Diuretic Activity of the Aqueous Extract Leaves of Ceiba pentandra (Bombacaceae) in Rats
}

\author{
Kemeta Azambou David Romain ${ }^{1 *}$, Ntchapda Fidele ${ }^{1}$, Dongmo Alain Bertrand ${ }^{2}$, \\ Talla Ernest Rodrigue ${ }^{1}$, Bayang Houli Nicolas ${ }^{3}$, Miaffo David ${ }^{4}$ and Dimo Théophile \\ ${ }^{1}$ Department of Biological Sciences, Faculty of Science, University of Ngaoundéré, \\ Cameroon, Po Box 454 \\ ${ }^{2}$ Department of Animal Biology, Faculty of Science, University of Douala, P O Box: 24157 \\ ${ }^{3}$ Laboratory of veterinary Research, Institute of Agricultural Research for Development \\ Wakwa, Ngaoundéré, Cameroon Po Box 65 \\ ${ }^{4}$ Department of Life and Earth Science, Higher Teachers' Training College, University of \\ Maroua, Cameroon Po Box 55 \\ ${ }^{5}$ Department of Animal Biology and Physiology, Faculty of Science, University of Yaoundé I, \\ Cameroon Po Box 812 \\ *Corresponding author
}

\section{Keywords}

Ceiba pentandra,

Diuresis,

Natriuretic,

Saluretic

Article Info

Accepted:

04 September 2019

Available Online:

10 October 2019
A B S T R A C T

Ceiba pentandra is a plant belonging to the family; Bombacaceae. In Cameroon it is used in traditional medicine for the treatment of arterial hypertension and a good number of other cardiovascular complications. This work is aimed at evaluating the sharp diuretic activity of the aqueous extract of Ceiba pentandra leaves in the rat. Male rats weighing between 150 and $180 \mathrm{~g}$ were chosen to carry out this study. Five doses of $(100,150,200,250$ and $300 \mathrm{mg} / \mathrm{kg})$ of the aqueous extract of Ceiba pentandra leaves were used. The selected animals were then distributed in to eight batches or groups of five rats each. The volume of urinary excretion, food and water intake were determined. The rats were the killed (sacrificed) $24 \mathrm{hrs}$ after treatment and the blood collected in heparinated tubes. The concentration of creatinine, urea, glucose, ALAT, ASAT and electrolytes $\left(\mathrm{Na}^{+}, \mathrm{K}^{+}, \mathrm{Cl}^{-}\right)$in blood and/or in the urine was evaluated with use of a spectrophotometer. Aqueous leave extract just like Furosemide and Amiloride brought in rats a significant increase $(p<0.05)$ and dependent dose of volume of urinary excretion compared to the negative control group. Meanwhile the dose of $300 \mathrm{mg} / \mathrm{kg}$ of the aqueous extract in rats brought a significant increase $(\mathrm{p}<0.05)$ of urinary excretion in $24 \mathrm{hrs}$ compared to groups or batches treated with Furosemide $(20.86 \%)$ and $69.50 \%$ Amiloride. This increase in urinary excretion is accompanied with a significant elimination $(\mathrm{p}<0.05)$ of $\mathrm{Na}^{+}$and $\mathrm{Cl}^{-}$ions while sparing $\mathrm{K}^{+}$and $\mathrm{Ca}^{2+}$ ions. The aqueous extract equally brought a significant increase $(\mathrm{p}<0.05)$ of the natriuretic, saluretic activities alongside the inhibition of carbonic anhydrase. Furthermore, we equally noted a significant increase $(p<0.05)$ of metabolic wastes (urea and creatinine) in the urine. The evaluation of glycemia revealed a significant decrease $(\mathrm{P}<0.05)$ in animals (rats) treated with the aqueous leaves extract from 33.75, 29.65 and $40.92 \%$ respectively for the doses of 200,250 and $300 \mathrm{mg} / \mathrm{kg}$ compared to the control group. The concentration in transaminase show a great decrease $(\mathrm{P}<0.05)$ of the concentration of ASAT from $22.46,46.79$ and $21.73 \%$, respectively for the doses of $250,300 \mathrm{mg} / \mathrm{kg}$ and Amiloride compared to control group. In contrast no significant change $(\mathrm{P}>0.05)$ in the rate of ASAT was observed in animals treated with the aqueous extract at the dose of $200 \mathrm{mg} / \mathrm{kg}$ as well as in the animals treated with Furosemide compared to the control group. The significant increase $(p<0.05)$ of urinary excretion as well as that of $\mathrm{Na}^{+}$and $\mathrm{Cl}^{-}$ions justify the use of this plant for it diuretic property in the treatment of arterial hypertension. 


\section{Introduction}

Cardiovascular diseases (CVDs) constitute a set of problems affecting the heart and the blood vessels. Among these pathologies we can cite coronary cardiopathy, cerebrovascular diseases, peripheral arteriopathy, rhumatismal cardiopathy, cardiac congenital malformation, deep (abstruse) veinous thrombosis and pulmonary embolism. Cardiovascular diseases are the major cause of death (mortality) in the world, each year it kills more people, more than the other diseases. It is estimated that $\mathbf{1 7 . 5}$ million is the number of death attributed to cardiovascular diseases, say, $31 \%$ of the global mortality rate [3]. In most countries undergoing development, the victims of cardiovascular diseases are two times higher than those caused by HIV/AIDS, malaria and tuberculosis put together ${ }^{[4]}$. In 2005, approximately eighteen million people died as a result of cardiovascular diseases in the world, about $80 \%$ of these deaths came from countries undergoing industrialization (development) ${ }^{[5]}$. It is estimated that in 2020 , cardiopathy is going to reach $120 \%$ in women and $137 \%$ in men in countries undergoing development if something is not done [6]. Some of the principal causes of cardiovascular diseases are: arterial hypertension, dyslipidemia, metabolic syndrome and cigarette consumption. ${ }^{[7]}$. Of these principal factors, arterial hypertension is known as one of the major risk factors responsible for cardiovascular disease ${ }^{[8]}$.

Arterial hypertension is a very important height (elevation) which persists although the subject is at rest from the force exerted by blood on the wall of arteries. Usually arterial pressure is evaluated by two digits: the first, the most elevated shows systolic arterial pressure or maximal blood pressure (that is when the heart contracts and pumps blood in the arteries and the second digit, the lowest corresponds to the minimal blood pressure or diastolic arterial pressure (that is when the heart relaxes) [9]. Arterial hypertension increases the risk of cerebral vascular disorder, coronary diseases, cardiac insufficiency, renal insufficiency and cognitive problems ${ }^{[10]}$. In Africa the prevalence rate of arterial hypertension is about $46 \%$ and about $37 \%$ in Cameroon ${ }^{[1]}$. The antihypertensive treatment still appeals to hygiene diet measures; the correction of metabolic associated abnormalities like hypercholesterolemia, diabetes etc at different levels of medication ${ }^{[11]}$.

In 1950, diuretics were the first medications administered for the treatment of arterial hypertension ${ }^{[12]}$. Nowadays, because of their efficiency, diuretics still serve in the treatment of light arterial hypertension, during first line care. In most countries undergoing development, access to conventional medicine remain limited to great agglomerations, difficulties to movement, little or no qualified staff, undesirable secondary effects, the high cost of accessing conventional medicine services and the socio-economic factors that does not give any other choice to the population than to go in for traditional medicine ${ }^{[13,14]}$.

Due to an increase in these diseases and generally the inability to afford conventional medicine, the World Health Organization, WHO AFR/RC50/R3 resolution of 31st august 2000, encourages African countries to elaborate regional strategies on traditional medicine in order to undertake research on medicinal plants and to promote their optimal usage in care and health service systems ${ }^{[15]}$. To reach the goal, a good number of researchers turned to ethno pharmacological approach especially (notably) in the cardiovascular domain. It is in this light that we undertook the evaluation of the diuretic properties of the aqueous extract of Ceiba pentandra leaves on rats. 
Ceiba pentandra is a big tree of the family Bombacaceae, reaching up to $50 \mathrm{~m}$ in height and $250 \mathrm{~cm}$ in diameter. The leaves, flowers and fruits when dried are used vegetables or ingredients cuisine (kitchen, cooking) ${ }^{[16]}$. The leaves, flowers and fruits have medicinal properties and allow for the alleviating painful affliction like fever, abscess, paronychia, mental ailments, conjunctivitis, dizziness, headache (cephalagia) and arterial hypertension. The bark is aphrodisiac, febrifuge and galactologue. It also allows for the treatment of sterility in women, cough, malaria, diarrhoea, gastralgia, gingivae (gingivitis), haemorrhoids etc.

This present study therefore has the principal aim of evaluating the diuretic properties of aqueous extract of Ceiba pentandra leaves in rats for $24 \mathrm{hrs}$ per administration.

\section{Materials and Methods}

\section{Plant Material}

In the course of this work, we used dried leaves of Ceiba pentandra (Bombacaceae). This plant was harvested (collected) in the locality of Dschang, Menoua division, West region of Cameroon then identified at the Herbier National of Cameroon by comparing with a registered sample under the number 3012/SRSK.

\section{Animal Material}

Forty (40) male albino rats of the Wistar strain, aged 2,5 to 3 months, weighing between 150 and $180 \mathrm{~g}$, domesticated in the laboratory of the Department of Biological Sciences of the Faculty of Science, were used for our study (work) University of Ngaoundere. These animals were acclimatized for about a week before being manipulated upon in the laboratory of Medicinal Plants, Health and Galenic Formulation of the
University of Ngaoundere. In the course of the process (manipulation), the animals were under the control and care of veterinary technician (doctor) of the Science and Veterinary Medicine, University of Ngaoundere. The animals were placed and controlled under the temperature of about $25 \pm$ $4{ }^{\circ} \mathrm{C}$ ) and relative humidity of about $45 \% \pm$ $10 \%$. They had access to ad libitum, to food and water. The procedure as well as the experimental protocol was endorsed (approved) by the Institution in charge of Animals and the research was approved by the Ethnic Committee of Animals of the University of Ngaoundere.

\section{Reference pharmacological substance}

Medicine such as Amiloride Hydro-CloroThiazide (AHCT) and Furosemide were used as reference diuretics.

\section{Preparation of aqueous extract}

Freshly harvested leaves of $C$. pentandra were dried under a shade then ground in order to obtain it powder and thereafter we introduced (added) $50 \mathrm{~g}$ of the powder in $1 \mathrm{~L}$ of cold water. We macerate for $12 \mathrm{hrs}$ on an agitator and the maceration process, the mixture was filtered with the help of the Wattman paper $n^{\circ} 3$. The filtrate was then dried freeze at $-40^{\circ} \mathrm{C}$, with the help of a lyophilisation machine, this permitted us to obtain $13,9 \mathrm{~g}$ of the powder giving a yield of about $27,8 \%$.

\section{Phytochemical study}

A phytochemical study was carried out to determined the different families of chemical compounds found in the bark of the trunk of $C$. pentedra responsible for it diuretic activity. For the identification of the different groups of metabolites in the raw (crude) aqueous extract, an analytical examination (test) at the Institute of Medicinal Plants for Medicinal research of 
Cameroon. As a result, the method describes by Chen and al., in $2011^{[17]}$ was used. A preliminary test of the phytochemical study was conducted for the identification of the different structures of the chemical compounds responsible for the diuretic activity of $C$. pentandra. Briefly and for instance, an essential oil of the aqueous extract of $C$. pentandra was extracted with hexane

\section{Evaluation of diuretic activity}

At the beginning of our manipulation, we realized a preliminary screening in order to proceed to the selection of rats that « urinated well ». As such, it consisted the oral administration of distilled water of $1 \mathrm{~mL} / 100 \mathrm{~g}$ body weight to rats. Rats treated as such were individually placed in their metabolic cages, the urine was collected and the urinary volume measured at the end of 6hrs. The animals haven excreted a volume above $40 \%$ of the volume of water were selected while those that excreted a volume less than $40 \%$ were excluded ${ }^{[18]}$. The selected animals were allocated (distributed) in 6 groups of 5 rats each individually placed in the metabolic cages for 7 days for acclimatization and after the period of acclimatization, the first three groups respectively received the aqueous extract of $C$. pentandra leaves at doses of 200, 250 and $300 \mathrm{mg} / \mathrm{kg}$. The last two groups made up of positive control group received the reference diuretics and the negative control group received distilled water. The volume of urinary excretion was determined at $3 \mathrm{hrs}$, $6 \mathrm{hrs}, 12 \mathrm{hrs}$ and $24 \mathrm{hrs}$ after the administration of a single dose of the different extracts. $24 \mathrm{hrs}$ after the administration of the different substances, the animals were killed (sacrificed) and blood was subsequently collected in EDTA tubes. All experimental procedure was approved by the Institution of Ethnic Committee of the Department of Biological Sciences of the University of Ngaoundere (ECDBSUN 15/01/2015/ UN/FS/DSB).

\section{Determination of the different parameters}

The treated animals were killed by decapitation (beheading) and the blood collected in EDTA tubes. The serum was separated by centrifugation at $3500 \mathrm{tr} / \mathrm{min}$ for 15 minutes then stored at $-20^{\circ} \mathrm{C}$ for the dosage of biochemical parameters such as creatinine, urea, sodium ion, potassium ion, chloride ion, ALAT and ASAT.

The urinary concentrations of sodium and potassium ions were determined with the aid of photometric flame (Jenway, PFP 7). The creatinine concentrations (Creat), urea and electrolytes in the samples of serum and urine were evaluated with the help of a bidirectional mass spectrophotometer. (Secomam RS 232C, France). In animals treated with the extract reference substance, urinary osmolarity and natriuresis were measured during the diuretic respond, particularly at maximal excretion levels. Osmolarity samples of plasma and urine was measured by cytometry with the help of an osmometer (Knauer). Osmolar clearance (Cosm) was determined from plasmatic osmolality (POSM), from urinary osmolarity (Uosm) and the urinary flow (debit, rate) (V) according to the relation (formula): Cosm = Uosm. V / POSM. The glomerular filtration rate (flow) (DFG) was evaluated by creatinine clearance (Creat). The quantity of $\mathrm{Na}+$ ion and $\mathrm{K}+$ ion was calculated according to the parameter for the saluretic activity. The relation $\mathrm{Na}+/ \mathrm{K}+$ was calculated for the natriuretic activity. To estimate the inhibition activity of carbonic anhydrase the following relation was used Cl$/(\mathrm{Na}++\mathrm{K}+)^{[19]}$.

\section{Determination of rectal temperature}

A digital thermometer was used to measure the rectal temperature. As a result, the transducer (sensor) end of the thermometer was introduced in the anus of the animal for a 
minute. All animals within the temperatures range of $35-38^{\circ} \mathrm{C}$ at the beginning of the experiment was selected meanwhile those that were having temperatures below or above the margin were eliminated. These temperatures were measured before and after $24 \mathrm{hrs}$ of administration of the different substances.

\section{Statistics analysis}

Each of these results are expressed or articulated as average \pm standard deviation $(n=5)$. The different statistics between the negative control group and the test groups were obtained thanks to ANNOVA test followed by Dennett's t test. The software analysis for variances had an origin of 8.0. The difference is significant if $\mathrm{P}<0.05$ and insignificant if $\mathrm{P}>0.05$.

\section{Results and Discussion}

\section{Phytochemical analysis}

The phytochemical study carried out on crude extracts with methanol and ethyl acetate the presence of several primary and secondary metabolites such as flavonoids, tannins, alkaloids, steroids and triterpens, saponins, les anthraquinons, phenol compounds and coumarins. Phenol compounds, notably triterpens, volatile oils and sterols were equally in the extract.

The presence of flavonoids and alcaloids is remarkable. The phytochemical results have been presented in table 1 below. Four fractions were collected and analysed to determine the presence of alcaloids, tanins, flavonoids and saponins.

These fractions were finally grouped into four and numbered A, B, C and D base on their predominant phytochemical reactions as indicated in table 1 below. These first observations and findings suggest that the aqueous extract of $\boldsymbol{C}$. pentandra leaves contain several chemical compounds with potential biological activity, meriting as such more and advanced research.

The effect of aqueous extract of Ceiba pentandra leaves on body temperature

During the experiment, no significant difference $(\mathrm{P}>0.05)$ was observed on the body temperature animal (Table 2).

Effect of the aqueous extract of Ceiba pentandra leaves on the lag phase of urinary excretion

Figure 1 below presents the effect of the aqueous extract of $C$. pentandra leaves on the lag phase of urinary excretion of rats. We remarked on this figure that there is a significant reduction $(\mathrm{P}<0.05)$ and the dependent dose of the lag phase of urinary excretion of (60 minutes for control at 32, 30, 20, 19 and 18 minutes respectively for the doses of 200, 250, $300 \mathrm{mg} / \mathrm{kg}$, Furosemide and Amiloride).

Effect of aqueous extract of Ceiba pentandra leaves on screening urinary volume

Table 3 below shows the effect of aqueous extract of the bark of $C$. pentandra on screening urinary volumes. From this table we observed that there is a significant increase $(\mathrm{P}$ $<0.05)$ of urinary excretion at time period of $6 \mathrm{hrs}, 12 \mathrm{hrs}$ and $24 \mathrm{hrs}$ in animals treated with the aqueous extract of different doses compared to the control group (i.e. treated with distilled water).

Meantime the volume of urinary excretion at doses $200 \mathrm{mg} / \mathrm{kg}(18,06 \mathrm{~mL} / \mathrm{kg}), 250 \mathrm{mg} / \mathrm{kg}$ $(21,9 \mathrm{~mL} / \mathrm{kg})$ and $300 \mathrm{mg} / \mathrm{kg}(31,94 \mathrm{~mL} / \mathrm{kg})$ showed an exponential increase of 117.06, 163.22 and $283.9 \%$ respectively at a time 
period of $24 \mathrm{hrs}$ compared to the control group $(8,32 \mathrm{~mL} / \mathrm{kg})$.

Effect of aqueous extract of Ceiba pentandra on cumulative urinary excretion

Cumulative urinary excretion increases significantly and at all time periods in animals treated with Furosemide and Amiloride compared to the control group. This significant increase varies at different time periods of $3 \mathrm{hrs}$, 6hrs, $12 \mathrm{hrs}$ and $24 \mathrm{hrs}$ ) from $291,9 \%, 188,9 \%, 39,37 \%$ and $41,10 \%$ for furosemide and 106,06\%,46,12\%,83\% and $173,07 \%$ for Amiloride respectively compared to the control group (Table 4). In animals treated with the aqueous extract of different doses 200, 250 and $300 \mathrm{mg} / \mathrm{kg}$ ), no significant difference $(\mathrm{P}>0.05)$ was observed on urinary excretion volume at a time period of $3 \mathrm{hrs}$ compared to the control group.

Contrary to the $3 \mathrm{hrs}$ time period, the administration of the plant extract of different doses brought a significant increase and in the dose dependent manner of the urinary excretion at different time intervals of 6hrs, $12 \mathrm{hrs}$ and $24 \mathrm{hrs}$. However it was equally noted that the plant extract at a dose of 300 $\mathrm{mg} / \mathrm{kg}$ brought a significant increase $(\mathrm{P}<$ 0.05 ) in the urinary volume at time interval of $12 \mathrm{hrs}(26,48 \mathrm{~mL} / \mathrm{kg} /$ time interval $)$ and $24 \mathrm{~h}$ $(31,94 \mathrm{~mL} / \mathrm{kg} /$ time interval) compared to Furosemide $(9,88 \mathrm{~mL} / \mathrm{kg} /$ time interval and $11,74 \mathrm{~mL} / \mathrm{kg} /$ time interval) and Amiloride $(8,08 \mathrm{~mL} / \mathrm{kg} /$ time interval and 22,72 $\mathrm{mL} / \mathrm{kg} /$ time interval). During the manipulation process, no significant change of urinary $\mathrm{pH}$ was observed in animals treated at different doses.

Effect of the aqueous extract of Ceiba pentandra leaves on the excretion of electrolytes

Table 5 below shows the effect of the aqueous extract of the bark of $C$. pentandra trunk on the excretion of electrolytes. We remarked in this table that the urinary excretion of $\mathrm{Na}^{+}$ions increased in a significant manner in animals treated with the aqueous extract at doses of $250 \mathrm{mg} / \mathrm{kg}(45,64 \mathrm{mmol} / \mathrm{L})$ and $300 \mathrm{mg} / \mathrm{kg}$ $(58,6 \mathrm{mmol} / \mathrm{L})$ say $5,8 \%$ and $35,89 \%$ respectively, as well as in animals haven received pharmacological reference substances $(8,9 \%$ and $27,41 \%$ respectively for Amiloride and Furosemide) compared to the control group $(43,12 \mathrm{mmol} / \mathrm{L})$. Rats treated with the aqueous extract at different doses just like the rats treated with Furosemide and Amiloride showed an insignificant increase in the urinary excretion of $\mathrm{K}^{+}$compared to the rats treated with distilled water.

Animals treated with the aqueous extract showed a significant increase in the excretion of chloride ions from $33 \%, 44,96 \%$ and 86 , $18 \%$ for the doses of 200, 250 and $300 \mathrm{mg} / \mathrm{kg}$ respectively compared to animals in the negative control. Likewise, Amiloride and Furosemide brought in rats a significant increase in the excretion of $\mathrm{Cl}^{-}$ions of 24, $38 \%$ and $73,36 \%$ compared to distilled water.

The urinary concentration $\mathrm{Ca}^{+}$ions significantly increased as in animals treated with the aqueous extract of different doses than those that received reference diuretics.

Furthermore, it was equally noted that the aqueous extract of the bark of $C$. pentandra trunk at a dose of $300 \mathrm{mg} / \mathrm{kg}$ brought a significant excretion $(\boldsymbol{\Delta} \mathrm{P}<0.05) \mathrm{Na}^{+}$and $\mathrm{Cl}^{-}$ ions respectively of $23,53 \%$ and $49,69 \%$ compared to Amiloride and 6, 66\% and 7, $40 \%$ compared to Furosemide.

Effect of the aqueous extract of Ceiba pentandra leaves on diuretic index and electrolytes indices in $24 \mathrm{hrs}$

Table 6 below shows the effect of the aqueous extract of $C$. pentandra leaves on the diuretic and electrolytes indices in 24hrs. We 
remarked from this table that the diuretic index increases in a dose dependent manner in animals treated with the aqueous extract as well as in those treated with reference medicine compared to the control.

Likewise, an increase in the index of $\mathrm{Na}^{+}, \mathrm{K}^{+}$, $\mathrm{Cl}^{-}$as well as $\mathrm{Ca}^{2+}$ ions was observed in rats treated with the plant extract than in those treated with furosemide and amiloride compared to the control rats meanwhile, the dose of $300 \mathrm{mg} / \mathrm{kg}$ showed a more elevated electrolytes and diuretic indices than the other doses.

\section{Effect of the aqueous extract of Ceiba pentandra leaves on the natriuretic, saluretic and CAI activity}

Natriuretic, saluretic activity as well as CAI was evaluated $24 \mathrm{hrs}$ after the administration of substances as seen in table 7 . Saluretic activity significantly increased and of the dose dependent manner in animals treated with plant extract $(15.29 \%, 23.73 \%$ and $58.89 \%$ doses for 200, 250 and $300 \mathrm{mg} / \mathrm{kg}$ ) respectively as well as in those that were treated with reference pharmacological substances $(16.03 \%$ and $48.42 \%$ respectively for furosemide and amiloride) compared to the animals treated with distilled water.

Likewise, CAI significantly increases in animals with the aqueous extract from $27.39 \%, 31.50 \%$ to $35.61 \%$ for the doses of 200,250 and $300 \mathrm{mg} / \mathrm{kg}$ respectively as well as in the animals treated with reference pharmacological substances $(12.32 \%$ and $37.26 \%$ for furosemide and amiloride) respectively in comparison to the control.

The dose of $300 \mathrm{mg} / \mathrm{kg}$ of saluretic showed a significant increase of $36.94 \%$ compared to furosemide and $7.05 \%$ compared to amiloride. The doses 200 and $250 \mathrm{mg} / \mathrm{kg}$ showed no significant change in the natriuretic activity compared to control. On the other hand, the dose $300 \mathrm{mg} / \mathrm{kg}$ as well as reference medicines brought a significant increase of $19.53 \%, 17.57 \%$ and $35.15 \%$ for the dose 300 $\mathrm{mg} / \mathrm{kg}$, furosemide and amiloride) respectively of the natriuretic activity compared to the control group.

Effect of the aqueous extract of Ceiba pentandra leaves on the functioning indices of the kidneys

Table 8 shows the values of biochemical parameters in urine. We remarked on this table that no significant change $(\mathrm{P}>0.05)$ in the rate of creatinine was observed in animals treated with aqueous extract of doses 200 and 250 $\mathrm{mg} / \mathrm{kg}$ as well as in those haven received furosemide compared to the control. In contrast, a significant increase $(\mathrm{p}<0.05)$ in the rate of creatinine from $47,56 \mathrm{mg} / \mathrm{dL}$ to $44,65 \mathrm{mg} / \mathrm{dL}$ respectively for the groups treated with the extract at the dose $300 \mathrm{mg} / \mathrm{kg}$ and in those treated with amiloride compared to the control $(36,43 \mathrm{mg} / \mathrm{dL}$ ) was observed (be it a respective increase rate of $30.55 \%$ and $22.56 \%$ ).

Creatinine clearance varies in animals treated with neither aqueous extract nor reference medicine. The aqueous extract administered at the doses 200 and $250 \mathrm{mg} / \mathrm{kg}$ increased significantly $(p<0.05) \quad$ creatinine clearance compared to the control (a respective percentage of $102,5 \%$ and $90 \%$ for instance). Likewise, furosemide and amiloride brought an increase of this clearance of $0,08 \pm 0,02$ and $0,09 \pm 0,01$ compared to $1,002 \pm 0,12$ respectively for the control.

The glomerular filtration rate increases significantly $(\mathrm{P}<0.05)$ and in a dose dependent manner in animals treated with the aqueous extract of $1,15 \pm 0,12,1,23 \pm 0,07,1,58 \pm 0,09$ for the of doses 200, 250 and $300 \mathrm{mg} / \mathrm{kg}$ respectively compared to the control $(0,93 \pm 0,12)$. 
In the same light, reference pharmacological substances brought a significant increase $(p<0.05)$ of glomerular filtration rate $(1,16 \pm 0$, 12 for furosemide and 1, 48 $\pm 0,15$ for amiloride) compared to the control $(0,93 \pm 0$, 12).

The administration of the aqueous extract just like furosemide and amiloride brought a increase in the concentration of urea in urine.

This concentration significantly increased $(\mathrm{p}<0.05)$ and in a dose-dependent manner in animals treated with the aqueous extract from $7,75 \%, 25,28 \%$ to $66,37 \%$ for doses 200,250 and $300 \mathrm{mg} / \mathrm{kg}$ respectively compared to the control group. In the same light, a significant increase in the concentration of urea in urine was observed in animals treated with $86,78 \%$ furosemide and 60, 34\% amiloride compared to the control.

Uosm significantly reduced $(\mathrm{p}<0.05)$ in animals treated with the aqueous extract as well as in animals treated with reference pharmacological substances $(42,30 \%, 40,10 \%$, $35,51 \%, 8,79 \%$ and $15,93 \%$ for the doses 200 $\mathrm{mg} / \mathrm{kg}, 250 \mathrm{mg} / \mathrm{kg}, 300 \mathrm{mg} / \mathrm{kg}$, furosemide and amiloride) compared to the animals control group.

The extract dose of $300 \mathrm{mg} / \mathrm{kg}$, for furosemide and amiloride increased significantly $(\mathrm{p}<0.05)$ the Cosm from $4,25 \%, 59,57 \%$ to $42,55 \%$ compared to distilled water. The Cosm of rats treated with the aqueous extract of doses 250 $\mathrm{mg} / \mathrm{kg}$ and $300 \mathrm{mg} / \mathrm{kg}$ reduced significantly $(\mathrm{p}<0.05)$.

The $\mathrm{C}_{\mathrm{H} 2 \mathrm{O}}$ significantly increased from 15 , $78 \%, 22,88 \%$ to 19 , and $29 \%$ respectively for the significant dose of extract, furosemide and amiloride (Table 8).
Effect of the aqueous extract of Ceiba pentandra leaves on blood parameters

Table 9 below shows the effects of the aqueous extract of Ceiba pentandra leaves on the biochemical parameters in the blood. On this table we notice a significant reduction in the concentration of urea from 74.07, 74.07, $51.85,51.85$ to $37.03 \%$ respectivement for the doses of $200,250,300 \mathrm{mg} / \mathrm{kg}$ respectively, Furosemide and Amiloride compared to the control.

During the manipulation process, a significant reduction $(\mathrm{P}<0.05)$ of glycemia was observed treated with the aqueous extract from $33.75 \%$, $29.65 \%$ and $40.92 \%$ for the doses 200, 250 and $300 \mathrm{mg} / \mathrm{kg}$ respectively compared to the control.

Likewise, we also observed a significant reduction $(\mathrm{P}<0.05)$ in glycemia of $27.76 \%$ in animals treated with Amiloride compared to the control rats. No significant change in glycemia was observed in animals treated with Furosemide. Similarly, no significant change $(\mathrm{P}>0.05)$ in the concentration of creatinine was observed in the animals during the manipulation process.

The concentration of ions $\left(\mathrm{Na}^{+}, \mathrm{Ca}^{2+}\right.$ et $\left.\mathrm{Cl}^{-}\right)$in the blood reduced in a significant manner $(\mathrm{P}<0.05)$ as in animals treated with the aqueous extract of the plant than in those that received Amiloride compared to the group treated with distilled water.

Similarly, we also noticed a significant increase in the Posm in animals treated with the aqueous extract with doses of 250 and 300 $\mathrm{mg} / \mathrm{kg}$, with furosemide and amiloride compared to those treated with distilled water. Contrarily, no significant change $(\mathrm{P}>0.05)$ in the concentration of potassium ions in the blood was observed. 
Table.1 Phytochemical analysis of the aqueous extract of $C$. pentandra leaves

\begin{tabular}{|c|c|c|c|c|c|c|}
\hline $\begin{array}{c}\text { Chemical } \\
\text { compound }\end{array}$ & $\begin{array}{c}\text { Indication of } \\
\text { leaves extract }\end{array}$ & Content (\%) & Fractions & & & \\
\hline Anthocyanin & + & $0.693 \pm 0.012$ & - & - & - & - \\
\hline Glycoside & + & $0.312 \pm 0.025$ & - & - & - & - \\
\hline Flavonoid & +++ & $16.210 \pm 0.162$ & +++ & - & - & - \\
\hline Alkaloid & ++ & $11.530 \pm 0.187$ & - & ++ & - & - \\
\hline Phenol & ++ & $0.457 \pm 0.035$ & - & - & - & - \\
\hline Steroids & ++ & $0.374 \pm 0.033$ & - & - & - & - \\
\hline Tannins & + & $0.268 \pm 0.048$ & - & - & - & ++ \\
\hline Saponins & ++ & $5.345 \pm 0.057$ & - & - & ++ & - \\
\hline
\end{tabular}

+++ , the presence of a very strong concentration of bioactive compounds;

++ , the presence of a strong concentration of bioactive compounds;

+ ,the presence of bioactive compounds.

Table.2 Effect of extract aqueous of the bark of C. pentandra on the body temperature

\begin{tabular}{|l|l|l|l|l|l|l|}
\hline $\begin{array}{l}\text { Doses } \\
(\mathbf{m g} / \mathbf{k g})\end{array}$ & control & $\mathbf{2 0 0}$ & $\mathbf{2 5 0}$ & $\mathbf{3 0 0}$ & $\begin{array}{l}\text { Furosemide } \\
\mathbf{( 5 m g / k g})\end{array}$ & $\begin{array}{l}\text { Amiloride } \\
(\mathbf{1 4 m g} / \mathbf{k g})\end{array}$ \\
\hline T initial $\left({ }^{\circ} \mathbf{C}\right)$ & $36,76 \pm 1,26$ & $36,88 \pm 0.64$ & $37,34 \pm 0,79$ & $36,78 \pm 1,01$ & $37,3 \pm 0,43$ & $37,54 \pm 0,85$ \\
\hline T final $\left({ }^{\circ} \mathbf{C}\right)$ & $36,7 \pm 0,99$ & $36,66 \pm 0,73$ & $36,66 \pm 1,39$ & $36,48 \pm 0,47$ & $36,96 \pm 0,53$ & $37,24 \pm 1,15$ \\
\hline
\end{tabular}

Each value represents the average \pm standard deviation, $n=5$. $T=$ temperature

Table.3 Effect of aqueous extract of $C$. pentandra on screening urinary volume

\begin{tabular}{|c|c|c|c|c|c|}
\hline \multicolumn{5}{|c|}{ Urinary volume $(\mathrm{mL} / \mathrm{kg})$} \\
\hline & & $3 \mathrm{hrs}$ & $6 \mathrm{hrs}$ & $12 \mathrm{hrs}$ & $24 \mathrm{hrs}$ \\
\hline & & $0,99 \pm 0,18$ & $2,45 \pm 0,9$ & $7,25 \pm 0,7$ & $8,32 \pm 1,32$ \\
\hline & 100 & $5,72 \pm 1,90^{*}$ & $4,56 \pm 1,11$ & $8,27 \pm 2,01$ & $11,33 \pm 2,00^{*}$ \\
\hline Control & 150 & $1,52 \pm 0,70$ & $5,47 \pm 0,47^{*}$ & $12,14 \pm 1,5^{*}$ & $13,93 \pm 2,3^{*}$ \\
\hline & 200 & $1,01 \pm 0,33$ & $6,42 \pm 1,42^{*}$ & $14,28 \pm 2,00^{*}$ & $18,06 \pm 1,58^{*}$ \\
\hline & 250 & $1,2 \pm 0,21$ & $6,8 \pm 1,8^{*}$ & $16,09 \pm 2,09 *$ & $21,9 \pm 2,91^{*}$ \\
\hline & 300 & $0,67 \pm 0,20$ & $13,87 \pm 1,51^{*}$ & $26,48 \pm 3,00^{*}$ & $31,94 \pm 2,94^{*}$ \\
\hline
\end{tabular}

Each value represents an average \pm standard deviation. $* \mathrm{P}<0.05$, a significant difference compared to control group (that is treated with distilled water). 
Table.4 Effect of aqueous extract of Ceiba pentandra leaves on the cumulative urinary excretion volume

\begin{tabular}{|c|c|c|c|c|c|c|}
\hline \multicolumn{6}{|c|}{ Urinary volume (mL/kg/time interval) } & \multirow[t]{2}{*}{$\mathrm{pH}$ value } \\
\hline & & $3 \mathrm{hrs}$ & $6 \mathrm{hrs}$ & $12 \mathrm{hrs}$ & $24 \mathrm{hrs}$ & \\
\hline \multicolumn{2}{|l|}{ control } & $0,99 \pm 0,18$ & $2,45 \pm 0,9$ & $7,25 \pm 0,7$ & $8,32 \pm 1,32$ & $7,38 \pm 0,15$ \\
\hline & 200 & $1,01 \pm 0,33$ & $6,42 \pm 1,42 *$ & $14,28 \pm 2,00 *$ & $18,06 \pm 1,58 *$ & $7,58 \pm 0,16$ \\
\hline \multirow[t]{2}{*}{ Extract $(\mathrm{mg} / \mathrm{kg})$} & 250 & $1,2 \pm 0,21$ & $6,8 \pm 0,21 *$ & $16,09 \pm 2,09 *$ & $21,9 \pm 2,91 *$ & $8,55 \pm 0,14$ \\
\hline & 300 & $0,67 \pm 0,20$ & $13,87 \pm 1,51 *$ & $26,48 \pm 3,00 * \boldsymbol{\Delta}$ & $31,94 \pm 2,94 * \boldsymbol{\Delta}$ & $7,75 \pm 0,2$ \\
\hline \multicolumn{2}{|c|}{ Amiloride (14 mg/kg) } & $2,04 \pm 0,94 *$ & $3,58 \pm 1,40 *$ & $8,08 \pm 1,94 *$ & $22,72 \pm 2,72 *$ & $7,50 \pm 0,18$ \\
\hline \multicolumn{2}{|c|}{ Furosemide $(5 \mathrm{mg} / \mathrm{kg}))$} & $3,88 \pm 0,86^{*}$ & $7,08 \pm 1,07 *$ & $9,88 \pm 1,40 *$ & $11,74 \pm 1,80 *$ & $7,76 \pm 0,18$ \\
\hline
\end{tabular}

Each value represents an average \pm standard deviation. $* \mathrm{P}<0.05$, a significant difference compared to the control group (distilled water); $\boldsymbol{\Delta} \mathrm{P}<0.05$, a significant difference compared to Amiloride and Furosemide.

Table.5 Effect of aqueous extract of Ceiba pentandra leaves on urinary excretion of electrolytes

\begin{tabular}{|c|c|c|c|c|c|}
\hline & & $\mathrm{Na}^{+}(\mathrm{mmol} / \mathrm{L})$ & $\mathrm{K}^{+}(\mathrm{mmol} / \mathrm{L})$ & $\mathrm{Cl}^{-}(\mathrm{mmol} / \mathrm{L})$ & $\mathrm{Ca}^{2+}(\mathrm{mg} / \mathrm{dL})$ \\
\hline \multicolumn{2}{|l|}{ Control } & $43,12 \pm 2,46$ & $6,05 \pm 0,77$ & $36,34 \pm 2,5$ & $41,96 \pm 2,26$ \\
\hline & 200 & $43,28 \pm 1,1$ & $7,96 \pm 0,17$ & $48,33 \pm 2,6^{*}$ & $50,38 \pm 2,23 *$ \\
\hline \multirow[t]{2}{*}{ Extract $(\mathrm{mg} / \mathrm{kg})$} & 250 & $45,64 \pm 2,01 *$ & $9,06 \pm 0,77$ & $52,68 \pm 5,63 *$ & $53,54 \pm 63,92 *$ \\
\hline & 300 & $58,6 \pm 2,1 * \wedge$ & $9,56 \pm 1,51$ & $67,66 \pm 2,2 * \boldsymbol{\Delta}$ & $63,92 \pm 2,2 *$ \\
\hline \multicolumn{2}{|c|}{ Amiloride (14 mg/kg) } & $47 \pm 1,31 *$ & $7,68 \pm 0,15$ & $45,2 \pm 6,08 *$ & $66,82 \pm 1,52 *$ \\
\hline \multicolumn{2}{|c|}{ Furosemide (5 mg/kg) } & $54,94 \pm 4,11 *$ & $7,93 \pm 0,1$ & $63 \pm 2,25^{*}$ & $59,56 \pm 1,21 *$ \\
\hline
\end{tabular}

Each value represents an average \pm standard deviation. $* \mathrm{P}<0.05$ a significant difference compared to the control (distilled water); $\boldsymbol{\Delta} \mathrm{P}<0.05$ a significant difference compared to Amiloride and Furosemide.

Table.6 Effect of the aqueous extract of Ceiba pentandra on electrolytes and diuretic indices in $24 \mathrm{hrs}$

\begin{tabular}{|c|c|c|c|c|c|c|}
\hline & & $\begin{array}{c}\text { Diuretic } \\
\text { index }\end{array}$ & $\begin{array}{c}\text { Index of } \\
\mathrm{Na}^{+}\end{array}$ & $\begin{array}{c}\text { index of } \\
\mathrm{K}^{+}\end{array}$ & $\begin{array}{c}\text { Index of } \\
\mathrm{Cl}^{-}\end{array}$ & $\underset{\mathrm{Ca}^{2+}}{\text { Index of }}$ \\
\hline Control & & 1,00 & 1,00 & 1,00 & 1,00 & 1,00 \\
\hline & 200 & 2,17 & 1,003 & 1,31 & 1,32 & 1,20 \\
\hline Extract $(\mathrm{mg} / \mathrm{kg})$ & 250 & 2,63 & 1,05 & 1,49 & 1,44 & 1,27 \\
\hline & 300 & 3,83 & 1,35 & 1,58 & 1,86 & 1,52 \\
\hline Furosemide (5 n & $\mathrm{g} / \mathrm{kg})$ & 1,41 & 1,08 & 1,26 & 1,24 & 1,59 \\
\hline Amiloride (14 m & $\mathrm{g} / \mathbf{k g})$ & 2,73 & 1,27 & 1,31 & 1,73 & 1,41 \\
\hline
\end{tabular}

Each value shows an average per dose. 
Table.7 Effect of the aqueous extract of Ceiba pentandra leaves on natriuretic, saluretic and CAI activities

\begin{tabular}{|c|c|c|c|c|c|c|c|}
\hline & & $\begin{array}{l}\text { Saluretic } \\
\text { activity } \\
\left(\mathrm{Na}^{+}+\mathrm{Cl}^{-}\right)\end{array}$ & $\begin{array}{c}\text { Natriuretic } \\
\text { activity } \\
\left(\mathrm{Na}^{+} / \mathbf{K}^{+}\right)\end{array}$ & $\begin{array}{c}\text { CAI Cl } \\
/\left(\mathbf{N a}^{+}+\mathbf{K}^{+}\right) \\
\text {activity }\end{array}$ & $\begin{array}{c}\text { Index } \\
\text { saluretic }\end{array}$ & $\begin{array}{l}\text { Natriuretic } \\
\text { index }\end{array}$ & $\begin{array}{r}\text { CAI } \\
\text { index }\end{array}$ \\
\hline Control & & $79,46 \pm 4,96$ & $5,12 \pm 3,19$ & $0,73 \pm 0,77$ & 1,00 & 1,00 & 1,00 \\
\hline & 200 & $91,61 \pm 3,7 *$ & $5,43 \pm 2,47$ & $0,93 \pm 2,04 *$ & 1,15 & 1.06 & 1,27 \\
\hline Extrcit (mg/kg) & 250 & $98,32 \pm 7,64^{*}$ & $5,03 \pm 2,61$ & $0,96 \pm 2,02 *$ & 1,23 & 0.98 & 1,31 \\
\hline & 300 & $126,26 \pm 4,3^{*} \boldsymbol{\Delta}$ & $6,12 \pm 1,39 *$ & $0,99 \pm 0,60 *$ & 1,58 & 1.16 & 1,35 \\
\hline Furosemide (5 m & $\mathrm{g} / \mathrm{kg})$ & $92,2 \pm 7,39 *$ & $6,11 \pm 1,73^{*}$ & $0,82 \pm 1,16^{*}$ & 1,16 & 1.19 & 1,12 \\
\hline Amiloride (14 m & $3 / \mathbf{k g})$ & $117.94 \pm 6.36^{*}$ & $6,92 \pm 1,1 *$ & $1,002 \pm 0,54^{*}$ & 1,48 & 1.23 & 1,37 \\
\hline
\end{tabular}

Each value shows an average \pm standard deviation. $* \mathrm{P}<0.05$ a significant difference compared to the control (distilled water); $\boldsymbol{\Delta} \mathrm{P}<0.05$ a significant difference compared to Amiloride and Furosemide.

Table.8 Effect of the aqueous extract of Ceiba pentandra leaves on the functioning index of the kidneys.

\begin{tabular}{|c|c|c|c|c|c|c|}
\hline Dose (mg / kg) & control & $\mathbf{2 0 0}$ & $\mathbf{2 5 0}$ & $\mathbf{3 0 0}$ & Furosemide & AHCT \\
\hline Creatinine (mg/dl) & $36,43 \pm 0,44$ & $38,78 \pm 0,53$ & $41,2 \pm 0,74^{*}$ & $47,56 \pm 2,68^{*}$ & $40,46 \pm 1,23^{*}$ & $44,65 \pm 0,79^{*}$ \\
\hline Creat Cl (ml/min) & $0,44 \pm 0,08$ & $0,83 \pm 2,04^{*}$ & $0,96 \pm 2,02^{*}$ & $0,99 \pm 0,60^{*}$ & $0,82 \pm 1,16^{*}$ & $1,002 \pm 0,54^{*}$ \\
\hline GFR (ml/min) & $0,93 \pm 0.12$ & $1,15 \pm 0,12^{*}$ & $1,23 \pm 0,7^{*}$ & $1,58 \pm 0,09^{*}$ & $1,16 \pm 0,12^{*}$ & $1,48 \pm 0,15^{*}$ \\
\hline Urea (mg/dl) & $348 \pm 0,44$ & $375 \pm 0,2$ & $436 \pm 0,6$ & $579 \pm 0,5^{*}$ & $650 \pm 0,5^{*}$ & $558 \pm 0,4^{*}$ \\
\hline Uosm (mOsmol/kg) & $182 \pm 9$ & $105 \pm 11^{*}$ & $109 \pm 15^{*}$ & $121 \pm 12^{*}$ & $166 \pm 12^{*}$ & $153 \pm 16^{*}$ \\
\hline $\mathbf{C o s m}(\mathbf{m L} / \mathbf{m i n})$ & $0.047 \pm 0.005$ & $0.044 \pm 0.012$ & $0.046 \pm 0.012$ & $0.049 \pm 0.017^{*}$ & $0.075 \pm 0.021^{*}$ & $0.067 \pm 0.011^{*}$ \\
\hline $\mathbf{C H}_{\mathbf{2}} \mathbf{O}(\mathbf{m L} / \mathbf{m i n})$ & $0.057 \pm 0.011$ & $0.056 \pm 0.012$ & $0.058 \pm 0.018$ & $0.066 \pm 0.016^{*}$ & $0.070 \pm 0.011^{*}$ & $0.068 \pm 0.013^{*}$ \\
\hline
\end{tabular}

Each value represents the mean $\pm \mathrm{ESM}, \mathrm{n}=5 . * \mathrm{P}<0.05$ significant difference compared to control $(\mathrm{ED}=$ Distilled Water $)$. $\mathrm{Cl}$ Crea $=$ Creatinine Clearance, GFR $=$ Glomerular Filtration Rate, AHCT $=$ Amiloride Hydrochlorothiazide.

Table.9 Effect of aqueous extract of Ceiba pentandra leaves on blood parameters

\begin{tabular}{|c|c|c|c|c|c|c|c|c|c|}
\hline & & Urea & Creatinine & Glucose & $\mathbf{N a}+$ & $\mathbf{K}+$ & Cl- & $\mathrm{Ca} 2+$ & $\begin{array}{c}\text { Posm } \\
(\mathrm{mOsmol} / \mathrm{kg})\end{array}$ \\
\hline \multicolumn{2}{|c|}{ Control } & $27 \pm 0,5$ & $0,46 \pm 0,02$ & $131,12 \pm 1,6$ & $107,79 \pm 1,13$ & $2,52 \pm 0,02$ & $97,94 \pm 1,44$ & $98,20 \pm 0,77$ & $250.12 \pm 21.21$ \\
\hline & 200 & $7 \pm 0,3 *$ & $0,55 \pm 0,04$ & $86,86 \pm 3,92 *$ & $99,97 \pm 0,89 *$ & $2,32 \pm 0,43$ & $94,80 \pm 3,27 *$ & $65,28 \pm 1,54 *$ & $255.23 \pm 2.23 *$ \\
\hline \multirow[t]{2}{*}{ Extract } & 250 & $7 \pm 0,2 *$ & $0,63 \pm 0,03$ & $92,23 \pm 3,7 *$ & $97,60 \pm 1,11 *$ & $2,82 \pm 0,16$ & $76,40 \pm 4,82 *$ & $54,46 \pm 1,42 *$ & $260.43 \pm 31.43 *$ \\
\hline & 300 & $13 \pm 0,4 *$ & $0,76 \pm 0,04$ & $77,46 \pm 1,27^{*}$ & $86,85 \pm 1,67 *$ & $3,33 \pm 0,44$ & $53,32 \pm 5,66^{*}$ & $62,18 \pm 1,33^{*}$ & $265.62 \pm 42.67 *$ \\
\hline \multicolumn{2}{|c|}{$\begin{array}{c}\text { Furosemide } \\
(5 \mathrm{mg} / \mathrm{kg})\end{array}$} & $13 \pm 0,2 *$ & $1,21 \pm 0,18$ & $129 \pm 1,78$ & $103,64 \pm 3,78$ & $3,29 \pm 0,20$ & $101,20 \pm 4.05$ & $124,66 \pm 3,14$ & $266.82 \pm 32.84 *$ \\
\hline \multicolumn{2}{|c|}{$\begin{array}{l}\text { Amiloride } \\
\text { (14mg/kg) }\end{array}$} & $17 \pm 0,2 *$ & $1,26 \pm 0,15$ & $94,72 \pm 3,99 *$ & $83,98 \pm 1,24 *$ & $3,47 \pm 0,30$ & $63,40 \pm 4,86^{*}$ & $61,20 \pm 0,27 *$ & $265.35 \pm 44.57 *$ \\
\hline
\end{tabular}

Each value represents the mean \pm ESM. $* \mathrm{P}<0.05$ a significant difference compared to the control (distilled water). 
Table.10 Effect of the aqueous extract of Ceiba pentandra leaves on the rate of transaminases

\begin{tabular}{|l|l|c|c|c|c|c|c|}
\hline \multicolumn{9}{|c|}{ Extract (mg/kg) } \\
\hline \multirow{2}{*}{ blood } & ASAT (UI) & $19,32 \pm 0,63$ & $18,74 \pm 0,70$ & $14,98 \pm 1,08$ & $10,28 \pm 1,22$ & $17,12 \pm 0,57$ & $15,12 \pm 1,35$ \\
\cline { 2 - 8 } & ALAT (UI) & $8,76 \pm 0,85$ & $12,64 \pm 1,90$ & $12,96 \pm 0,71$ & $14 \pm 1,58$ & $8,68 \pm 1,01$ & $7,20 \pm 1,30$ \\
\hline
\end{tabular}

Each value represents the mean \pm ESM.

Fig.1 Effect of aqueous extract of $C$. pentandra leaves on the lag phase of urinary excretion. Each bar represents the average \pm standard deviation. $* \mathrm{P}<0.05$, significant compared to the control.

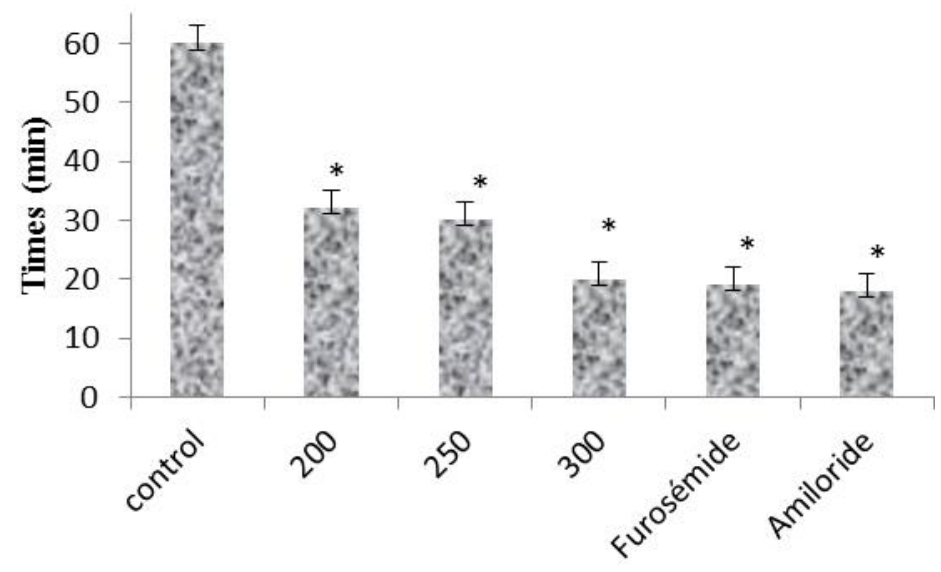

Effect of the aqueous extract of Ceiba showed the presence of some bioactive pentandra leaves on the rate of compounds. Amongst these families of transaminases

The rate of transaminases in the blood evaluated in the course of our manipulation and recorded in the table 10 shows a significant reduction $(\mathrm{P}<0.05)$ in the concentration of ASAT from 22.46, 46.79 and $21.73 \%$ of doses of $250, \quad 300 \mathrm{mg} / \mathrm{kg}$ respectively and Amiloride compared control group. In contrast, no significant change $(\mathrm{P}>0.05)$ in the rate of ASAT in animals treated with the aqueous extract with a dose of $200 \mathrm{mg} / \mathrm{kg}$ as well as in those animals that were treated with Furosemide compared to the control. In the same light, the concentration of ALAT showed no significant change in the different test groups compared to the control.

The phytochemical analysis results done on the aqueous extract of Ceiba pentandra leaves compounds, some had a capital role as far as the diuretic power of the plant is concerned. Flavonoids were the compounds that induce diuresis by reacting either individually or in association with other substances ${ }^{[20]}$.

Rectal temperature evaluated in the course of the experiment showed no significant change in the animals. This relates the fact that the aqueous extract of Ceiba pentandra leaves have no anti pyretic activity. These same results were obtained by Ntchapda et al., in $2015^{[18]}$ with aqueous extract of the bark of avec Zanthoxylum heitzii trunk had no antipyretic activity on rats.

The increase in the urinary excretion observed during screening in animals treated with the aqueous extract with doses of 200, 250 and $300 \mathrm{mg} / \mathrm{kg}$ relate to the fact that these doses 
are effective doses of medicine. The dose of $300 \mathrm{mg} / \mathrm{kg}$ of the extract brought a strong increase in urinary excretion at time interval $6 \mathrm{hrs}, 12 \mathrm{hrs}$ and $24 \mathrm{hrs}$ compared to both positive and negative test control groups. This increase in dieresis could be due to the presence of families of chemical compounds such as flavonoids, saponosids and triterpens ${ }^{[21]}$. It is probable that this increase in urinary excretion brought by the aqueous extract of $C$. pentandra leaves may have come from the synergic effects of several active substances in the extract and these effects could have been due to active secondary metabolites ${ }^{[18]}$.

According or based on our results, we noticed that the elimination of urine was accompanied by a high elimination of electrolytes. The high elimination of $\mathrm{Na}^{+}$and $\mathrm{Cl}^{-}$ions observed with the dose of $300 \mathrm{mg} / \mathrm{kg}$ of the extract and the group treated with furosemide show their natriuretic and saluretic effects. The elimination of $\mathrm{Na}^{+}$ions by the different doses of the extract of $C$. pentandra just like furosemide is explained by the effect of the aqueous extract of furosemide on different segment of the nephron ${ }^{[22]}$. So this may be explained by the fact that the aqueous extract of $C$. pentandra is acting by inhibiting the reabsorption of $\mathrm{Na}^{+}$and water at the level of the descending loop of Henle [23]. The presence of the sodium pump between the tubular cell and the interstitial liquid prevent sodium from migrate towards the tubular cell [24]. The energy necessary for the functioning of the sodium pump is supplied by membranous ATPase. The urinary excretion of sodium and to a lesser extend potassium seems to indicate that the extract has an inhibitory effect on this sodium pump ${ }^{[21]}$.

The elimination of sodium ions may be equally due to the fact that the effect of the aqueous extract on the distal convulated tubules and collecting duct of the nephron by inhibiting the reabsorption of water and sodium ${ }^{[25]}$. Furthermore, the increase in the excretion $\mathrm{Na}^{+}$ions may equally be due to the inhibiting effect of the aqueous extract, which is acting by inhibiting the conversion of the enzyme angiotensine, bringing a reduction in the secretion of aldosterone, favouring in this way the increase in urinary excretion of sodium ${ }^{[26]}$. Moreover, an increase in the excretion of sodium reduces speed of glomerular filtration by increasing the charge in $\mathrm{Na}^{+}$necessary for the exchange of $\mathrm{Na}^{+} \leftrightarrow$ $\mathrm{K}^{+}$and also by stimulating these exchanges by intermediary of hyperaldosteronism it causes and in this way, reducing the mass of blood ${ }^{[18]}$.In fact, a good diuretic is one that induces a great elimination of sodium while sparing potassium ${ }^{[27,28]}$. Our results showed a high elimination of sodium ions and a low elimination of potassium ions. It could be that all the potassium filtered by the glomerulus either actively reabsorbed at the proximal tubules. The low quantity of potassium seen in the urine result from the secretion by the distal tubules and the collecting ducts in exchange with the reabsorption of sodium and in competition with the secretion of sodium ions. The reduction in the excretion of $\mathrm{K}^{+}$ions explains hypokaliuretic effect of the aqueous extract of $C$. pentandra and thereby justifying the increase in natriuretic activity.

Our study showed a significant increase $(\mathrm{p}<0.05)$ in the natriuretic activity with a dose of $300 \mathrm{mg} / \mathrm{kg}$ of the extract just like the reference medicines compared to the negative test groups. The work led by Ntchapda and $a l$., in $2015^{[18]}$, showed that when the relation $\left(\mathrm{Na}^{+} / \mathrm{K}^{+}>02\right)$, of the aqueous extract has an important natriuretic activity, bringing then a more elevated urinary excretion of sodium than that of potassium.

Our results corroborate the study of Sanogo and al., $2009^{[29]}$, on diuretic and salidiuretic activity of a process used in traditional medicine for the treatment of arterial 
hypertensions. Similarly, when the activity of $\mathrm{CAI}<0,8$, this shows a reduction in the diuretic activity ${ }^{[18]}$. Our plant extract just like amiloride and furosemide showed an activity of $\mathrm{CAI}>0,8$, hence a strong diuretic activity.

Creatinine and urea are markers for the kidney functioning. The results obtained during our work on these two markers showed a significant change of the rate of creatinine in the groups that have received furosemide and amiloride compared to the negative control au group. Moreover, analysis also showed that the concentration of urea and creatinine in the urine presents a significant difference between groups treated with the aqueous extract and negative control group. In fact, creatinine just like urea is essentially eliminated from blood by glomerular filtration. An increase in the rates of urea and creatinine in urine observed in the batches treated with the aqueous extract could be due to plant effect on the glomerulus bringing then a good glomerular filtration, thereby eliminating metabolic wastes ${ }^{[28]}$.

The analysis of results showed a reduction in dependent dose in glomerular filtration flow obtained from creatinine clearance. This reduction could be due to an increase in the excretion of $\mathrm{Na}+$ ions which serves to reduce DFG by increasing the charge of $\mathrm{Na}+$ ions available for the exchange of $\mathrm{Na}+\mathrm{K}+$, stimulating such an exchange beyond by hyperaldosteronism which causes a reduction in the volume of blood ${ }^{[30]}$.

The biochemical parameters in the blood showed a decrease in dependent dose of glycemia and uremia. Urea, considered as a marker for renal dysfunctioning, generally has a normal serous concentration [31]. The decrease in the rate of urea noticed in the blood in animals treated with the aqueous extract could be due to it significant elimination the kidneys. The decrease of glycemia, uremia and electrolytes in animals treated with the aqueous extract can be attributed to the fact that, besides it diuretic effect $C$. pentandra also possesses antihyperglycemic ability, has an effect in the elimination of metabolic wastes and contribute to the excretion of electrolytes $\left(\mathrm{Na}^{+}\right.$and $\left.\mathrm{Cl}^{-}\right)$

The aqueous extract of Ceiba pentandra leaves has brought no significant reduction of serous transaminases. This decrease can be explained by the presence of some chemical substances such as flavonoids, saponosids and alkaloids in the plant extract which are known for their anti oxidizing activity hence hepato protective ${ }^{[32]}$. Similarly, a study led by Barrakat and al., in $2011^{[33]}$ showed that diuretics have anti oxidizing properties, so this can also be that $C$. pentandra have anti oxidizing and as such behaves as an antihypertensive.

The outcome of our work shows that the aqueous extract of Ceiba pentandra leaves effectively possesses diuretic properties and more over reduces arterial pressure during excretion of urine, it equally contributes to the excretion of electrolytes as well as elimination of metabolic wastes.

\section{References}

Abegunde D. O., Mathers C. D., Adam T., (2007). The burden and costs of chronic diseases in low income and middleincome countries. Lancet 2007; 370: 1929-38.

Amuthan A, Chogtu B, Bairy KL, Sudhakar, Prakash M. (2012). Evaluation of diuretic activity of Amaranthus spinosus Linn. Aqueous extract in Wistar rats. J Ethnopharmacol. 140(2): 424-427.

Barakat L. and Mahmoud R. (2011). The antiatherogenic, renal protective and immunomodulatory effects of purslane, pumpkin and flax secds on hypercholesterolemic rats. J North Am., 3: 351-357. 
Blacher J., Jean-Michel M., Olivier H., JeanJacques M., Atul P., Bruno S., Xavier G., (2013). Prise en charge de l'hypertension artérielle de l'adulte Recommandations 2013 de la Société Française d'Hypertension Artérielle. Recommandations, mt 2014; 20(1): 39$47 \mathrm{p}$

Chen JJ, Lin YH, Day SH, Hwang TL, Chen IS. New benzenoids and anti-inflammatory constituents from Zanthoxylum nitidum. Food Chem. 2011; 125(2): 282-287.

Choudhuy P. K and Jadhaw S., (2013). Acute toxicity studies of methanolic Bark extract of Ficus racemosa and root extract of Cissampelos pareira. International journal of pharma and bio sciences. Vol (2): pp 1050-1055b

Cloutier L., Anne-Marie L., Sophie L., Maria N., (2013). Traitement pharmacologique de l'HTA partie 1.Pratique clinique 2ACFA,vol 10 (1), p37.

Cloutier L., Anne-Marie L., Sophie L., Maria N., (2013). Traitement pharmacologique de l'HTA partie 1.Pratique clinique 2ACFA,vol 10 (1), p37.

DCEM1, 2007. module cardiovasculaire, Les Diurétiques.doc. Faculté de médecine

Delahaye F. J. Y., Artigou J. C., Daubert et Huques M., (2008). Cardiologie $\left(3^{\mathrm{e}}\right.$ édition), Paris, Elsevier Masson, 540 p.

Éloi D., Aurélie F., Béatrice G., and Sylvie J., (2014). Mortalité prématurée par maladies cardiovasculaires chez les hommes selon la catégorie sociale et le secteur d'activité. 01;

Fézan H., Tra bi., Guy M., Irié., Kohué C. C., N'gaman., and Clejesson H.B. M., (2008). Études de quelques plantes thérapeutiques utilisées dans le traitement de l'hypertension artérielle et du diabète: deux maladies émergentes en Côte d'Ivoire. Sciences and Nature, 5(1), 39 - 48;

Fhayli W., (2013). Evaluation de l'action de traitements chroniques par l'extrait d'aneth ou le minoxidil en tant que nouvelles pharmacothérapies antivieillissement du système cardiovasculaire chez la souris. Université de Grenoble

Ghosh S. M., Kapil V., Fuentes-Calvo I., Bubb K. J., Pearl V., Milsom A. B., Khambata R., Maleki-Toyserkani S., Yousuf M., Benjamin N., Webb A. J, Caulfeld M. J, Hobbs A. J., Géraldine d'Ythurbide, Alexandre Hertig. (2012). Savoir interpréter une créatininémie pour apprécier la fonction rénale est essentiel. La revue du praticien médecine générale 1 tome $261 \mathrm{n}^{\circ} 8761$.

Guindo I., (2006). Etude du traitement traditionnel de l'hypertension arterielle au Mali. Thèse, Universite de Bamako, République du Mali 139p.

Jagannath N., Shravani P., Naga T. P. A., Damodaram G., Somashekar S. C., (2017). Study of diuretic activity of aqueous extract of Amaranthus spinosus linn on rats, International Journal of Basic and Clinical Pharmacology, Vol 6 (1), p 144.

Katilé B., (2014). Contrôle de qualité et étude des paramètres phytochimiques d'un médicament traditionnel: le Nitrokoudang utilisé dans le traitement de l'HTA au Mali. Thèse de Doctorat de l'Université des Sciences, des Techniques et des Technologies de Bamako Faculté de Pharmacie, République du Mali, 140p.

Mitra S., Sharma P.K., Avnesh K. S., Vipin K. G., Sambhu C. M., (2012). Herbal drugs used as diuretics. AN International Journal of Pharmaceutical Sciences, Vol-3, Issue-2 ISSN: 0976-7908

Ngo B., Taiwe G.S., Moto F.C.O., Ngoupaye G.T., Nkancthoua G.C.N., Pelanken M.M and Rakotonirina S.V. (2009). Anticonvulsivant, Anxiolytic, and sedative propertie of the roots of Nauclea latifolia Smith in mice, Epilepsy Behav, 15:434-440;

Ntchapda F., Dimo T., Atchade A. T., (2010). Antihypertensive effets of the methylene chloride leaf extract of Celtis durandii Engler (Ulmaceae) in rats. International 
Journal of Biological and Chemical Sciences. 4(3): 642-648.

Ntchapda F., Dimo T., Mbongué F. G. Y., Atchade A. T., Kamtchouing P\& Enow O. G. (2008). Acute toxic effects of the aqueous leaf extract of Celtis durandii Engler (Ulmaceae) on mice. West Afr. J. Pharmacol. Drugs Res. vol. 24. pp 2429.

Ntchapda F., Maguirgue K., Michel A.T. F., Olivier M. P., Djedouboum A and Théophile D. (2015). Evaluation of the diuretic effects of crude stem bark extraction of Zanthoxylum heitzii (Rutaceae) in Wistar rats. Journal of Integrative Medicine Vol.13, No.5

Okafor, J. C., Ham, R., (1999). Identification, utilisation et conservation des plantes dans le sud est du Nigeria, in Thèmes de la biodiversité africaine bulletin $\mathrm{n}^{\circ} 3 ; 8$ p.

OMS, (2007). Health status: mortality. WHO Library Cataloguing-in-Publication Data; World health statistics. pp. 17-5

OMS, (2009). Aide-mémoire maladies cardiovasculaires. Disponible en ligne à l'adresse

http://www.who.int/mediacentre/factshe ets/fs317/fr/index.html. pp :1-6

OMS, (2017). Plan d'action mondial pour la lutte contre les maladies non transmissibles 2013-2020

Postel-Vinay $\mathrm{N}$ et Bobrie G. (2006). L'hypertension artérielle Unité d'hypertension artérielle, Cespharmar : éducation et prévention pour la santé Hôpital Européen Georges-Pompidou, Paris;
Prakash, B, Singh, P., Mishra, PK., Dubey, NK., 2011. Safety assessment of Zanthoxylum alatum Roxb. essential oil, its antifungal, antiaflatoxin, antioxidant activity and efficacy as antimicrobial in preservation of Piper nigrum L. fruits. Int J Food Microbiol., 2: 183-191.

Raynaud M. H., (2009). Maladies cardiovasculaires dans les pays en développement : Les faits.

Sanogo R., Karadji A.H., Dembélé O. and Diallo D. (2009). Activité diurétique et salidiurétique d'une recette utilisée en médecine traditionnelle pour le traitement de l'hypertension artérielle; Faculté de Médecine, de Pharmacie et d'Odontostomatologie, Université de Bamako, Département Médecine Traditionnelle BP. 1746 Bamako, pp 1

Saudy S. P-P., María M. E-C and María E. MC., (2016). Diuretic activity of the bark of Eysenhardtia polystachya. Bangladesh Journal of Pharmacology 11: 212-217.

Sunitha Ch., Rao K. N. V., David B., Sandhya S., Shwetha D. M. K., (2011). Diuretic activity on different extracts and formulation on aerial parts of Rumex vesicarius. Linn. Journal of Chemical and Pharmaceutical Research, 3(6):400408.

Whitby I.G., Smith A.F. and Beckett G.J., (1988). Lecture note of clinical chemistry. 4th edition black well scientific publications, oxford. 153-154.

\section{How to cite this article:}

Kemeta Azambou David Romain, Ntchapda Fidele, Dongmo Alain Bertrand, Talla Ernest Rodrigue, Bayang Houli Nicolas, Miaffo David and Dimo Théophile. 2019. Diuretic Activity of the Aqueous Extract Leaves of Ceiba pentandra (Bombacaceae) in Rats. Int.J.Curr.Microbiol.App.Sci. 8(10): 191-206. doi: https://doi.org/10.20546/ijcmas.2019.810.020 